\title{
Determination of testicular estrogen receptor alpha expression of male chickens (Gallus domesticus) with age
}

\author{
W. K. Ramesha Nirmali ${ }^{1,2}$, Lakshan Warnakula², Ruwini Cooray ${ }^{2}$, Nimanie Sachithra Hapuarachchi ${ }^{2}$ and \\ Manjula P. S. Magamage ${ }^{1}$
}

\begin{abstract}
1. Laboratory of Reproductive Biology and Animal Biotechnology, Department of Livestock Production, Faculty of Agricultural Sciences, Sabaragamuwa University of Sri Lanka, Belihuloya, Sri Lanka; 2. Section of Genetics, Institute for Research and Development, Colombo, Sri Lanka.

Corresponding author: Manjula P. S. Magamage, e-mail: manjula.magamage@fulbrightmail.org

Co-authors: WKRN: rameshanirmali@ymail.com, LW: lakshanwarnakula@gmail.com, RC: krncooray@live.co.uk, NSH: nimaniesh@gmail.com
\end{abstract}

Received: 08-02-2019, Accepted: 13-05-2019, Published online: 08-07-2019

doi: 10.14202/vetworld.2019.994-997 How to cite this article: Nirmali WKR,Warnakula L, Cooray R, Hapuarachchi NS, Magamage MPS (2019) Determination of testicular estrogen receptor alpha expression of male chickens (Gallus domesticus) with age, Veterinary World, 12(7): 994-997.

\begin{abstract}
Background and Aim: Estrogen activity, a central component of reproductive growth, is regulated by the receptor proteins, estrogen receptor alpha $(\mathrm{ER} \alpha)$, and ER beta $(\mathrm{ER} \beta)$ in chickens as in many other species. ER $\alpha$ expresses predominantly in gonads. Although the expression of ER $\alpha$ in embryonic gonads has been studied in detail, the expression of ER $\alpha$ in posthatching male gonads has not been studied adequately. Therefore, the current research was conducted to determine the posthatching changes in the expression of ER $\alpha$ in the left gonads of male chickens with age.
\end{abstract}

Materials and Methods: Shaver Brown male chickens were raised and cared for according to the management guide and sacrificed at the intervals of 1,4 , and 8 weeks of age. The total RNA was extracted from the left gonads using the Trizol method and reverse transcribed using a pair of gene-specific primers. Following polymerase chain reaction amplification, the expression of ER $\alpha$ was quantified relative to the expression of the reference gene GAPDH.

Results: The results showed that ER $\alpha$ expression significantly increases with age at $\mathrm{p}=0.0032$. However, the increment of ER $\alpha$ expression from week 1 to week 4 was 2.04-fold and from week 4 to week 8 was 1.39 -fold, with the later age reflecting a diminishing pattern in the increment.

Conclusion: These results differentiate the post-hatching ER $\alpha$ expression of the left gonads of male chickens increase with age but with a diminishing gradient that may support their reproductive functions in later stages of life.

Keywords: age, chicken, estrogen receptor alpha, gene expression, testicular.

\section{Introduction}

Estrogen is the primary female sex hormone which is responsible for the development and regulation of the female reproductive system and secondary sex characteristics [1]. Cellular estrogen activity is regulated by receptor proteins called estrogen receptors (ERs) which has two subtypes in vertebrates, ER alpha $(E R \alpha)$ and ER beta $(E R \beta)[2,3]$. Research over the past two decades shows estrogen also plays a key role in the development and regulation of the male reproductive system [4]. Aromatase is the crucial enzyme responsible for the synthesis of estrogens by aromatization of the androgens [5]. Synthesis of estrogen and the relationship of estrogen and male reproductive performances have been previously studied in many species [6,7]. In the testes of adult roosters, estrogen is secreted by Leydig cells and immature germ

Copyright: Nirmali, et al. Open Access. This article is distributed under the terms of the Creative Commons Attribution 4.0 International License (http://creativecommons.org/licenses/ by/4.0/), which permits unrestricted use, distribution, and reproduction in any medium, provided you give appropriate credit to the original author(s) and the source, provide a link to the Creative Commons license, and indicate if changes were made. The Creative Commons Public Domain Dedication waiver (http:// creativecommons.org/publicdomain/zero/1.0/) applies to the data made available in this article, unless otherwise stated. cells where the aromatase gene is expressed [6]. In developing embryonic gonads, the expression of ER $\alpha$ has been observed differently in males and females (higher in females) while ER $\beta$ expressed indifferently in the two sexes demonstrating that $\alpha$-type is more sex specific in chicken gonads [2]. The embryonic studies show that the early embryonic gonads (bipotential gonads) display ER $\alpha$ expression in the left but not in the right gonads of both sexes before gonadal differentiation [8]. Following gonadal differentiation (embryonic day 5), the expression of ER $\alpha$ gradually diminishes in males while expresses at higher concentrations in females [2,9-11]. These findings facilitate the previous argument that the ER $\alpha$ receptor is more sex specific in chickens. Further studies, therefore, are necessary to elucidate the actual role of ER $\alpha$ in the development of the reproductive system of male chickens.

Although the gonads show a diminishing trend of $\mathrm{ER} \alpha$ during embryonic stage, the research involved in ER $\alpha$ expression of adult testes shows that the testicular and epididymal regions contain varying amounts of ER $\alpha$ reflecting its importance in the reproductive development of chickens during later stages of life [12]. This contradiction creates a research gap with the variation 
in the ER $\alpha$ expression in the testicular region of chickens with age. Understanding this variation will provide important insights about the activity and the requirement of estrogen within the male gonads toward reproductive development with age. According to literature, when birds are exposed to xenoestrogens, it is said to cause feminizing effects in the genetic male birds causing reproductive failures [13].

Therefore, to maximize male chicken reproductive potential, it is important to determine the natural level of ER $\alpha$ expression in the male gonads to identify the abnormal estrogen activity which could be detected by elevated ER $\alpha$ expression due to exogenous estrogen exposure in birds. This study was aimed to investigate the variation of the ER $\alpha$ expression in the left gonads of male chickens with age.

\section{Materials and Methods \\ Ethical approval}

All animal experiments were conducted under the guidance and approval of the Institutional Animal Care and Use Committee recommendations of Sabaragamuwa University of Sri Lanka.

\section{Care of chicks}

All chicks were raised according to the guidelines given in the Shaver Brown Management Guide [14].

\section{Sacrificing chickens and sample collection}

Three chicks were sacrificed at the age of 1 week, 4 weeks, and 8 weeks by inserting an air bubble through the brachial vein using a $1 \mathrm{~mL}$ syringe attached to a sterile 29 gauge needle. Following sacrifice, the carcasses were dissected and the testes were removed. The left testes were immediately placed in a small volume of Phosphate-buffered saline and transported on ice to the laboratory for further analysis.

\section{RNA extraction and quantification}

The total RNA from the frozen left testes was extracted by the FavorPrep ${ }^{\mathrm{TM}}$ Tri-RNA Reagent (FAVORGEN Biotech Corp., Taipei, Taiwan) using the manufacturer's protocol with slight modifications [15]. Extracted RNA was quantified at $260 \mathrm{~nm}$ wavelength using a Nanodrop 2000 spectrophotometer (Thermo Scientific, USA). Purity of the samples was determined by $260 / 280$ and $260 / 230$ ratios.

\section{Reverse transcription (RT) and cDNA synthesis}

Extracted RNA of ER $\alpha$ was reverse transcribed using a gene-specific primer set described by Sakimura et al. [2] (Table-1). The reaction was performed using the FireScript ${ }^{\circledR}$ RT Kit (Solis BioDyne, Estonia) according to the FireScript Kit datasheet protocol [16]. The resulting cDNA was stored at $-20^{\circ} \mathrm{C}$ until future RT polymerase chain reaction (PCR) analysis was conducted.

\section{PCR amplification of ERa}

About $1 \mu \mathrm{L}$ of the RT product (cDNA) was used to amplify the ER $\alpha$ sequence using the forward and reverse primers previously described by Sakimura et al. [2]. PCR was performed with initial denaturation at $94^{\circ} \mathrm{C}$ for
$2 \mathrm{~min}$, followed by 40 cycles of denaturation at $97^{\circ} \mathrm{C}$ for $10 \mathrm{~s}$, annealing at $55^{\circ} \mathrm{C}$ for $30 \mathrm{~s}$, and extension at $72^{\circ} \mathrm{C}$ for $1 \mathrm{~min}$ and final extension for $2 \mathrm{~min}$ at $72^{\circ} \mathrm{C}$.

\section{PCR amplification of GAPDH}

GAPDH was used as the reference gene to quantify the relative expression of ER $\alpha$. About $1 \mu \mathrm{L}$ of the RT product from each sample was amplified. Initial denaturation was conducted at $94^{\circ} \mathrm{C}$ for $2 \mathrm{~min}$, followed by 40 cycles of denaturation at $97^{\circ} \mathrm{C}$ for $10 \mathrm{~s}$, annealing at $50^{\circ} \mathrm{C}$ for $30 \mathrm{~s}$, and extension at $72^{\circ} \mathrm{C}$ for $1 \mathrm{~min}$ and a final extension for $2 \mathrm{~min}$ at $72^{\circ} \mathrm{C}$.

\section{Agarose gel electrophoresis}

PCR amplicons were electrophoresed in $1.5 \%$ agarose gel, which was prestained with 30,000 times diluted diamond dye in $1 \times \mathrm{TBE}$ buffer. Electrophoresis conditions were $60 \mathrm{~V}$ for $1.5 \mathrm{~h}$, and the DNA was visualized directly on a blue light transilluminator.

\section{Relative quantification of ERa expression and statis- tical analysis}

ER $\alpha$ expression was semi-quantified using Image $\mathrm{J}$ (National Institutes of Health and the Laboratory for Optical and Computational Instrumentation, USA), an image processing software, and the mean intensity of the bands was used for the expression analysis. ER $\alpha$ expression as a percentage of the GAPDH expression was calculated in each sample using the mean intensity values. Relative expressions were statistically analyzed using a one-way ANOVA procedure of Statistical Analysis Software (SAS version 9.0) (SAS Institute, USA) to test the effect of age on the ER $\alpha$ expression in the left gonads of the male chickens.

\section{Results and Discussion}

The relative expression of ER $\alpha$ showed a significant increase with age (Figures-1 and 2). Statistically it was significant with $p$-value of 0.0032 . The least square mean comparison test specified that there is a significant difference between each age interval (Table-2). These results provide evidence of the rise in ER $\alpha$ expression in the left gonads of male chickens with age.

This finding contradicts the embryonic ER $\alpha$ expression results, which showed a diminishing expression of the ER $\alpha$ in male left gonads following gonadal differentiation. Therefore, this embryonic expression reduction can be interpreted as a sex-specific mechanism to support the differentiation of the bipotential gonads based on their genetic sex. Nevertheless, this finding is in compliance with the previous finding by the Gonzalen-Moran et al. [17], which displayed the highest ER $\alpha$ expression in testicles of mature chickens than in immature chickens showing an increment of ER $\alpha$ expression with age.

The post-hatching increase of the ER $\alpha$ expression in the gonads can be justified to support the increased activity of the estrogen in gonads for the reproductive development in male chicken with age, as per the latest finding of the role of estrogen in the male reproductive 
Table-1: Primer details of ER $\alpha$ expression analysis [2].

\begin{tabular}{lclr}
\hline Fragment name & Amplicon size (bp) & Primer sequence (5' to $\mathbf{3}^{\prime}$ ) & Temperature ( $\left.{ }^{\circ} \mathbf{C}\right)$ \\
\hline ER $\alpha$ forward & 300 & GTGCCTTAAGTCCATCATCCT & 59.4 \\
ER reverse & \multirow{2}{*}{348} & GCGTCCAGCATCTCCAGTAAG & 63.3 \\
GAPDH forward & & GTGGAGAGATGACAGAGGTG & 60.5 \\
GAPDH reverse & & AACAAGCTTGACGAAATGGT & 54.3 \\
\hline
\end{tabular}

$\mathrm{ER} \alpha=$ Estrogen receptor alpha

Table-2: p-values for least squares mean comparison for male chicken.

\begin{tabular}{lccc}
\hline p-values & Week 1 & Week 4 & Week 8 \\
\hline Week 1 & & 0.0133 & 0.0011 \\
Week 4 & 0.0133 & & 0.0220 \\
Week 8 & 0.0011 & 0.0220 & \\
\hline
\end{tabular}

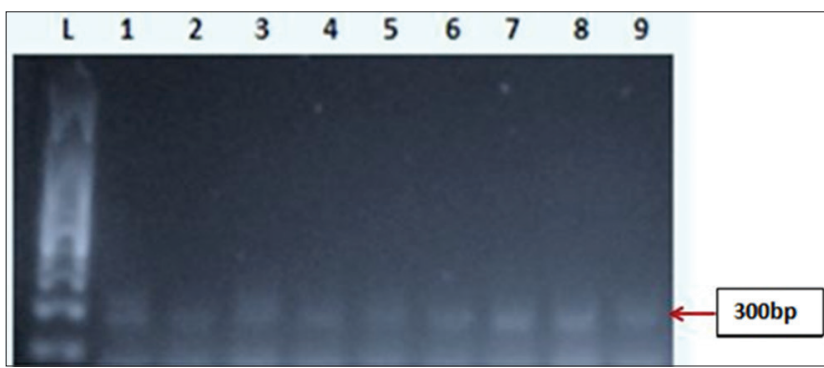

Figure-1: Electrogram for estrogen receptor alpha (ERa) expression in chicken gonads. L: 100 bp ladder, 1-3: ERa expression of week 1 chickens, 4-6: ERa expression of week 4 chickens, 7-9: ERa expression of week 8 chickens.

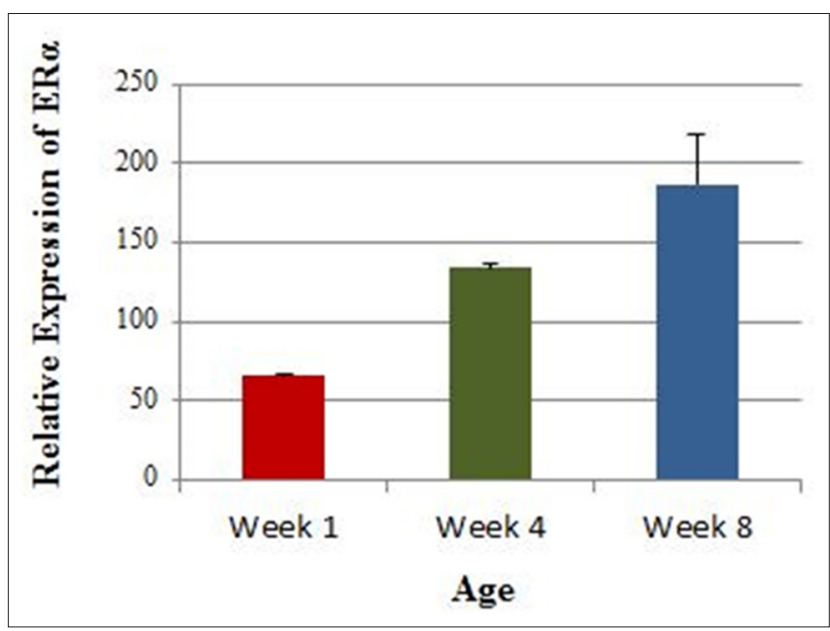

Figure-2: Variation of estrogen receptor expression with age.

system observed in many species $[4,18,19]$. The studies involved in male infertility and ER knocked down mice models revealed that estrogen activity which is crucial in spermatogenesis and seminal fluid secretion is mediated by the ER $\alpha$ and hence holds utmost importance in the mammalian male testes $[19,20]$. A similar role of ER $\alpha$ expression could be suggested for avian model too with the results of the current study.

However, a study on domestic goose provided contrasting evidence to this which showed an inverse proportionate of $\mathrm{ER} \alpha$ expression in testes with the plasma estrogen concentration during annual reproductive cycle [7]. Conversely, the sex reversal trials of chicken model suggested an induced expression of ER $\alpha$ in the embryonic male left gonads with an in ovo estradiol treatment $[2,8]$. This contradiction creates a gap for further research to check the variation of expression and the role of ER $\alpha$ in the testes of male birds with the age.

The experiment duration of the current study was 8 weeks and the sexual maturity of male chickens usually attains at 16 weeks of age [21]. Therefore, the results of the current study give an idea about the variation of the ER $\alpha$ expression during the presexual maturity period of chickens. The results also revealed that the post-hatching increase of ER $\alpha$ expression shows a diminishing pattern, by increasing from week 1 to week 4 in 2.04-fold and from week 4 to week 8 in 1.39-fold. This result gives speculation that the testicular ER $\alpha$ expression in chickens increases with age and comes to a peak at a certain age where the optimum reproductive development is facilitated and then declines or remains constant thereafter.

However, the previous research has evidence that the highest number of Sertoli cells and Leydig cells was found in immature chicken testicles, and the number drastically drops with the age [17]. Therefore, with the previous evidence of ER $\alpha$ expression confining to Sertoli cells and Leydig cells, the diminishing pattern of the increment of ER $\alpha$ expression can be explained as a result of the diminishing of these cells in the growing testicles. Although with a diminishing gradient, the increase of ER $\alpha$ expression with age can be suggested to support the other mechanisms behind the reproductive development such as production of seminal fluid and regulation of spermatogenesis. Nevertheless, it was also found that ER $\alpha$ expression was higher at the middle age than the aged chickens while there can be low amount of germ cells in aged chickens compared to middle-aged [17]. Combining the evidence from all studies, it can be suggested that the post-hatching ER $\alpha$ expression increases with a diminishing gradient up to a peak at a certain age and then it again declines with age corresponding to the reduction of the reproductive performance of chickens. However, further studies are essential to determine the role of $E R \alpha$ in the male reproductive development of the chicken model.

\section{Conclusion}

Considering the results obtained from this research, it can be suggested that the ER $\alpha$ expression in the male left testes increases with age with 
a diminishing pattern of the increment during the presexual maturity period of chickens.

\section{Authors' Contributions}

WKRN contributed to conceptualization, investigation, data curation, and original manuscript draft. LW helped with the methodology, investigation, funding acquisition, data curation, and editing. RC and NSH helped with the methodology, investigation, analysis, and validation. MPSM contributed to conceptualization, funding acquisition, supervision, visualizations, editing, and review. All authors corrected the manuscript and read and read and approved the final manuscript.

\section{Acknowledgments}

The authors would like to acknowledge the Institute for Research and Development for partially funding and facilitating the molecular analysis part of this research. They also would like to acknowledge the Research Farm and Department of Livestock Production, Faculty of Agricultural Sciences, Sabaragamuwa University of Sri Lanka for facilitating the incubation and field activities of the research.

\section{Competing Interests}

The authors declare that they have no competing interests.

\section{Publisher's Note}

Veterinary World remains neutral with regard to jurisdictional claims in published institutional affiliation.

\section{References}

1. Bondesson, M., Hao, R., Lin, C.Y., Williams, C. and Gustafsson, J.A. (2015) Estrogen receptor signaling during vertebrate development. Biochim. Biophys. Acta, 1849(2): 142-151.

2. Sakimura, M., Tsukada, A., Usami, M., Hanzawa, S., Saito, N., Ohno, Y. and Shimada, K. (2002) Effect of estradiol and nonylphenol on mRNA expression of estrogen receptors $\alpha$ and $\beta$, and cytochrome P450 aromatase in the gonad of chicken embryos. J. Poult. Sci., 39(4): 302-309.

3. Miyagawa, S., Lange, A., Hirakawa, I., Tohyama, S., Ogino, Y., Mizutani, T., Kagami, Y., Kusano, T., Ihara, M., Tanaka, H., Tatarazako, N., Ohta, Y., Katsu, Y., Tyler, C.R. and Iguchi, T. (2014) Differing species responsiveness of estrogenic contaminants in fish is conferred by the ligand binding domain of the estrogen receptor. Environ. Sci. Technol., 48(9): 5254-5263.

4. Cooke, P.S., Nanjappa, M.K., Ko, C., Prins, G.S. and Hess, R.A. (2017) Estrogens in male physiology. Physiol. Rev., 97(3): 995-1043.

5. Mair, K.M., Wright, A.F., Duggan, N., Rowlands, D.J., Hussey, M.J., Roberts, S., Fullerton, J., Nilsen, M., Loughlin, L., Thomas, M. and MacLean, M.R. (2014) Sexdependent influence of endogenous estrogen in pulmonary hypertension. Am. J. Respir. Crit. Care Med., 190(4): 456-467.

6. Hess, R.A. (2003) Estrogen in the adult male reproductive tract: A review. Reprod. Biol. Endocrinol., 1: 52.

7. Leska, A., Kiezun, J., Kaminska, B. and Dusza, L. (2015) Estradiol concentration and the expression of estrogen receptors in the testes of the domestic goose (Anser anser F. domestica) during the annual reproductive cycle. Domest. Anim. Endocrinol., 51: 96-104.

8. Nakabayashi, O., Kikuchi, H., Kikuchi, T. and Mizuno, S. (1998) Differential expression of genes for aromatase and estrogen receptor during the gonadal development in chicken embryos. J. Mol. Endocrinol., 20(2): 193-202.

9. Andrews, J.E., Smith, C.A. and Sinclair, A.H. (1997) Sites of estrogen receptor and aromatase expression in the chicken embryo. Gen. Comp. Endocrinol., 108(2): 182-190.

10. Smith, C.A., Andrews, J.E. and Sinclair, A.H. (1997) Gonadal sex differentiation in chicken embryos: Expression of estrogen receptor and aromatase genes. J. Steroid Biochem. Mol. Boil., 60(5-6): 295-302.

11. Guioli, S., Nandi, S., Zhao, D., Burgess-Shannon, J., LovellBadge, R. and Clinton, M. (2014) Gonadal asymmetry and sex determination in birds. Sex. Dev., 8(5): 227-242.

12. Oliveira, A.G., Dornas, R.A.P., Mahecha, G.A.B. and Oliveira, C.A. (2011) Occurrence and cellular distribution of estrogen receptors ER $\alpha$ and ER $\beta$ in the testis and epididymal region of roosters. Gen. Comp. Endocrinol., 170(3): 597-603.

13. Blomqvist, A., Berg, C., Holm, L., Brandt, I., Ridderstråle, Y. and Brunström, B. (2006) Defective reproductive organ morphology and function in domestic rooster embryonically exposed to o,p'-DDT or ethynylestradiol. Biol. Reprod., 74(3): 481-486.

14. A Hendrix Genetics Company, Netherlands. Shaver Brown Management Guide. Available from: https://www.kenanaonline.com/files/0082/82972/Shaver\%20Management $\% 20$ Guide.pdf. Last accessed on 15-08-2017.

15. Favorgen Biotech Corp, Taipe. FavorPrep ${ }^{\mathrm{TM}}$ Tri-RNA Reagent. Available from: http://www.favorgen.com/ pdf/DataSheet/Nucleic_Acid_Extraction/Total_RNA/ FATRR_001.pdf. Last accessed on 15-08-2017.

16. Solis Bio Dyne Data Sheet, Estonia. FIRE Script RT cDNA Synthesis KIT. Available from: https://www.sbd.ee/ pics/7696_Data_Sheet_FIREScript_RT_cDNA_Synthesis KIT.pdf. Last accessed on 15-08-2017.

17. Gonzalen-Moran, M.G., Guerra-Ariza, C., Campos, M.G. and Camacho-Arroyo, I. (2008) Histological and sex steroid hormone receptor changes in testes of immature, mature and aged chickens. Domest. Anim. Endocrinol., 35(4): 371-379.

18. Hess, R.A. and Carnes, K. (2004) The role of estrogen in testis and the male reproductive tract: A review and species comparison. Anim. Reprod., 1(1): 5-30.

19. Chimento, A., Sirianni, R., Casaburi, I. and Pezzi, V. (2014) Role of estrogen receptors and g protein-coupled estrogen receptor in regulation of hypothalamus pituitary testis axis and spermatogenesis. Front. Endocrinol., 5(1): 1-9.

20. Li, T.F., Wu, Q.Y., Zhang, C., Li, W.W., Li, N., Cui, Y.X., Li, X.J. and Xia, X.Y. (2014) Polymorphisms in estrogen receptors predict the risk of male infertility: A meta-analysis. Reprod. Biol. Endocrinol., 12: 79.

21. Elfwing, M., Nätt, D., Goerlich-Jansson, V.C., Persson, M., Hjelm, J. and Jensen, P. (2015) Early stress causes sex-specific, life-long changes in behavior, levels of gonadal hormones, and gene expression in chickens. PLoS One, 10(5): e0125808. 